University of California, Hastings College of the Law UC Hastings Scholarship Repository

Faculty Scholarship

2011

\title{
No Innocents Here Using Litigation to Fight Against the Costs of Universal Service in France
}

Dorit Rubinstein Reiss

UC Hastings College of the Law, reissd@uchastings.edu

Follow this and additional works at: http://repository.uchastings.edu/faculty_scholarship

\section{Recommended Citation}

Dorit Rubinstein Reiss, No Innocents Here Using Litigation to Fight Against the Costs of Universal Service in France, 1 Creighton International \& Comparative Law Journal 5 (2011).

Available at: http://repository.uchastings.edu/faculty_scholarship/1168

This Article is brought to you for free and open access by UC Hastings Scholarship Repository. It has been accepted for inclusion in Faculty Scholarship by an authorized administrator of UC Hastings Scholarship Repository. For more information, please contact marcusc@uchastings.edu. 


\title{
NO INNOCENTS HERE: USING LITIGATION TO FIGHT AGAINST THE COSTS OF UNIVERSAL SERVICE IN FRANCE
}

\author{
Dorit Rubinstein Reiss*
}

\section{INTRODUCTION}

A major difference between United States and European practice and outlook is found in the relationship of regulation to competition. In the United States, opening a utility market to competition is described as "deregulation." In Europe, however, opening market to competition is seen as requiring careful regulation after monopoly rights and duties are cancelled, to prevent abuses from powerful corporate actors and protect valuable interests. ${ }^{1}$ When I carelessly referred to the liberalization of the telecommunications market as "deregulation," a Swedish interviewee corrected me: "No. Before, we had an unregulated monopoly. Now, we have regulated competition." " One reason for this difference in perspective can be attributed to a difference in starting points. The United States had traditionally provided utilities by means of licensed monopolies, which while heavily regulated were still privately held companies, while most countries in Europe provided utilities through nationalized industries administered directly by the state in some way. Thus, the U.S. already had a vast array of regulation in play, some of which was eliminated in order to permit competition. Another factor is that several countries in Europe distrust the market to deliver certain kinds of goods and thus see a need for careful regulation. Those involved in regulating the newly competitive sectors correctly recognize that the greatest danger to successful liberalization is the previous state monopoly (the "incumbent"), both because of its size and power and because it has every incentive not to cooperate with the liberalization in normal circumstances. ${ }^{3}$ Although in specific cases operators may have interests

\footnotetext{
* Associate Professor, UC Hastings College of the Law. I am grateful to Bruce Carruthers, David Coolidge, Aaron Rappaport, and François Varloot for very useful comments to previous versions of this project and to Frederic Carteron and Shelley Kennedy for invaluable research assistance and input.

1 Vincent Wright, Public Administration, Regulation, Deregulation and Reregulation, in MANAGING PUBLIC ORGANIZATIONS: LESSONS FROM CONTEMPORARY EUROPEAN EXPERIENCE 244, 252-253 (Kjell A. Eliassen and Jan Kooiman eds., 1993) (describing the European context and showing that the result of reforms to liberalize sectors was reregulation, not just deregulation); STEVEN K. VOGEL, FREER MARKETS, MORE RULES 16-18 (1996) (demonstrating that privatization led to deregulation, focusing on cases from Britain and Japan); Giandomenico Majone, Cross-National Sources of Regulatory Policymaking in Europe and the United States, 11 J. OF PUB. POL'Y 79, 85 (1991). This description is somewhat simplistic; careful observers of regulation across both Europe and the United States emphasize the connection between state withdrawal from delivery and public services and a growth in regulation. See, Creating Competitive Markets: The Politics of Regulatory Reform (Marc K. Landy et al. eds. 2007). Nonetheless, I believe it captures differences in the basic approaches.

${ }^{2}$ Interview with a member of the Swedish Post and Telecom Agency, in Stockholm, Sweden (Sept. 7, 2004). Some of the information included in this article has not appeared in publication before and is based on original empirical research conducted through open ended interviews with actors in Sweden, France and England in 2004. The interviews were conducted under guarantees of anonymity, as required to get the approval of the Institutional Review Board at UC Berkeley working under federal regulations to protect human subjects. For that reason, the names of the interviewees, and on occasion (when it's too revealing) the specific location of the interview, will not be reported, though the date of the interview and the institutional affiliation of the interviewees will be reported.

3 Peter Cameron, Competition in Energy Markets: LaW and Regulation in the European Union 8, 18 , 5556 (2002); Damien Geradin, The Opening of State Monopolies to Competition: Main Issues of the Liberalization Process, in The Liberalization of STATE Monopolies in the European Union and Beyond, 181, 181-183 (Damien Geradin ed., 1999); Helena Lindskog, The Telecommunications Market In Sweden From Monopoly To
} 
that would lead them to support the move to liberalization, ${ }^{4}$ they are less likely to support the new obligations placed on them following liberalization: they will naturally want to maximize the advantages accruing to them from liberalizing while minimizing the restrictions placed on their use of their market power. To balance this power advantage of the previous incumbents, European Union institutions regulating utilities sectors tend to focus on enforcing competition. ${ }^{5}$ This approach comfortably fits the emphasis in the EU treaties on ensuring free movement of goods and services and preventing protectionism of large national firms against competition. ${ }^{6}$

However, the incumbent operator is not the only powerful economic actor in European member states. Some of the new entrants are also powerful corporations. The natural image of the new entrant in communications for many laypeople is the small communications start up, ${ }^{7}$ which can be described in contrast to huge, impersonal multi national corporations or huge incumbents that initially dominate the market. But many of the operators entering the European communications market are "new entrants" to a specific country, but as described in part 1.b, in no other way resemble a small start up. ${ }^{8}$ These sophisticated, powerful economic actors naturally want to maximize the benefits from liberalization. One avenue for them is to use the European Institutions to promote the aspects of liberalization they prefer - for example, access to the incumbent network - and at the same time use them to avoid the counterweights put in place to prevent harm from liberalization and avoid obligations put in place to protect valuable interests. That is not to say that these actors do not need protection against the incumbent, with its inherent advantages, just to caution that they should not be automatically seen as the "under dog," a David needing help against a Goliath. That is not a criticism of these new entrants; part of the philosophy behind liberalization is that the entry of new competitors would bring the benefits of free market competition to the sector. Sophisticated competitors, out to maximize their benefits,

Competition, Paper presnted at the 2004 Applied Business Research Conference, San Juan, Puerto Rico, 9 (2004), available at: http://www.heldag.com/articles/Telecom\%20market $\% 20 \mathrm{ABR} \% 202004 \% 20 \% 20 \mathrm{H} \% 20 \mathrm{Lindskog}$.pdf. (Last visited April 16, 2010).

${ }^{4}$ For example, Thatcher convincingly argued that telecommunications operators in Europe supported liberalization and achieving freedom from the government as a way to reduce political control over them and political intervention in their actions and to get better access to capital. See Mark Thatcher, The National Politics of European Regulation: Institutional Reform in Telecommunications, in UTILITIES REFORM IN EUROPE 11, 13 (David Coen \& Mark Thatcher eds., 2001); Mark Thatcher, Winners and Losers in Europeanisation: Reforming the National Regulation of Telecommunications, 27 W. EUR. POL. 284 (2004) [hereinafter Thatcher 2004]. For electricity, several authors showed that EDF, France's incumbent electricity operator supported, even though reluctantly, some liberalization since it would allow it to expand to other markets and it believed it is in a good position to withstand competition. Ian Bartle, When Institutions No Longer Matter: Reform of Telecommunications and Electricity in Germany, France and Britain, 22 J. PUB. POL'Y 1, 16 (2002); Rainer Eising, Policy Learning in Embedded Negotiations: Explaining EU Electricity Liberalization, 56 INT'L ORGS. 85, 97-99; Rainer Eising \& Nicolas Jabko, Moving Targets: National Interests and Electricity Liberalization in the European Union, 34 COMP. POL. STUD. 742, 745-47 (2001). This willingness to support initial liberalization, however, does not undermine the point made here: the operators may have an interest in some liberalization, but they also have an interest in preserving their own market power as much as possible within the liberalized market.

${ }^{5}$ Vivien A. Schmidt, Europeanization and the Mechanics of Economic Policy Adjustment, 9 J. EUR. PUB. POL'Y 894, 908 (2002); Thatcher 2004, supra note 4.

${ }^{6}$ Joachim Scherer, Electronic Communication Law and Policy of the European Union, in TELECOMMUNICATIONS LAW IN EUROPE: LAW AND REGULATION OF ELECTRONIC COMMUNICATIONS (Joachim Scherer ed., 5th ed. 2005); Christian Joerges, Good Governance Through Comitology?, in EU COMMITTEES: SOCIAL REGULATION, LAW AND POLITICS 311, 316 (Christian Joerges \& Ellen Vos eds., 1999); Schmidt, supra note 5 at 906.

7 Some examples of smaller telecommunications companies include Primus Telecommunications, www.pirumustel.co.uk, Thus, http://mediacentre.thus.net/company-information/, and Voxbone, www.voxbone.com.

${ }^{8}$ See infra, notes 34-39 and the accompanying text. 
can probably balance the weight of the incumbent better than only small new companies, and thus contribute to competition. But the designers of the system and its regulators need to be aware that this is a battle of giants, and design the system to prevent abuses from either side.

This Article demonstrates that this concern is not only theoretical, by telling the story of how French operators attempted to avoid their universal service obligations through European and then French litigation. In 2001, the European Court of Justice ("ECJ") found the French system of funding universal service in telecommunications to be in violation of EU law. ${ }^{9}$ Subsequent funding decisions were repeatedly attacked by operators in the French administrative courts, especially the Conseil d'État, for a number of reasons.

The decision and its aftermath can be seen-as the ECJ clearly saw it-as another attempt by France to put obstacles in the path of new entrants. Under this view, France does not share the ideology of free competition and unregulated markets and is anxious to protect its national champion, France Télécom, from competition through all means fair or foul. However, the battle around funding universal service can also be seen in another light—as a carefully thought out attack by sophisticated competitors on a regulatory scheme protecting a value they had no wish to pay for, universal service. A similar strategy_litigating to fight regulation-was adopted in the United States by industry actors unhappy with regulation aimed at them or burdens put on them. ${ }^{10}$ This paper suggests that that approach better fits existing data, and will be useful for understanding the behavior of the operators after the ECJ decision, when they brought repeated cases against universal service decisions by the French regulator.

Three general lessons emerge from this different reading of the battle around French Universal Service Funding. First, it supports the warning mentioned above, that the incumbent may not be the only actor with an incentive to combat or subvert the post-liberalization regulatory framework, and that regulators and courts should be wary of abuses of the system by new entrants too. Second, there is a real tension between the need to provide private actors a forum in which to defend themselves against excessive regulation and to protect their rights and the need to prevent use of the court system to cause delays and torpedo regulation. Ways to resolve that tension need to be considered. Finally, France's universal service experience emphasizes the importance of designing regulatory systems to prevent potential problems (or create procedural safeguards in the right places) — an issue considered in other contexts. ${ }^{11}$ In this

\footnotetext{
${ }^{9}$ Case C-146/00, Commission v. France, 2001 E.C.R. I-9767.

${ }^{10}$ In the Telecommunications context, see Rebecca Beynon, The FCC's Implementation of the 1996 Act: Agency Litigation Strategies and Delay, 53 FED. COMM. L.J. 27, 28 (2000). Though Beynon attributes much of the blame for the litigation to the commission. $I d$. at 29.; John M. de Figueiredo, Litigating Regulation: Corporate Strategy in Telecommunications 1-2 (2000) (copy available with author) available at http://web.mit.edu/jdefig/www/papers/litigation_regulation.pdf (last visited April 22, 2010); Terrence P. McGarty, Current Telecommunications Legal Issues, Litigation v. Legislation: Is the 1996 Act a Beginning or an End? (MIT ITC working paper, 2002) (copy available with author) available at: http://www.telmarc.com/2002_10_25\%20Current\%20Legal.pdf (last visited April 22, 2010); but see (noting that the danger is from the regulators and judicial review is necessary). On the negative role of courts in making it harder to regulate, see Thomas $O$. McGarity, The Courts and the Ossification of Rulemaking: A Response to Professor Seidenfeld, 75 TEX. L. REV. 525, 539-56 (1997).

${ }^{11}$ Dara K. Cohen et al., Crisis Bureaucracy: Homeland Security and the Political Design of Legal Mandates, 59 STAN. L. REV. 673, 712-13, 745-46 (2006) (noting why agencies are not always designed for success); Robert F. Durant, Agency Evolution, New Institutionalism, and 'Hybrid' Policy Domains: Lessons from the 'Greening' of the U.S. Military, 34 Pol'y Stud. J. 469, 469-71 (2006); David E. Lewis, PResidents and The Politics OF Agency Design: Political Insulation in the United States Government BureaucraCy, 1946-1997 6-7 (2003); Terry M. Moe, The Politics of Bureaucratic Structure, in CAN THE GOVERnMENT GOVERN, 267, 268-69 (John Chubb \& Paul Peterson eds., 1989); B. Dan Wood \& John Bohte, Political Transaction Costs and the Politics of
} 
specific context, the French experience casts doubts on the desirability of using an operatorsupported fund to finance public service operators may not value. Operators are more apt to act strategically to block a large annual assessment than they are to object to the addition of a small monthly charge to customers' bills.

Part I of this Article describes the French market post liberalization, and the framework put in place by France to fund universal service. Part II describes the version of the story reflected in the ECJ decision. Part III suggests the alternative version and describes the data supporting it. Part IV discusses the implications of the story. This Article then concludes with some general observations.

\section{Funding Universal SERVICE IN France}

\section{A. The Framework For Funding Universal SERVICE}

European Union law requires all member states to open their telecommunications market to competition as of 1998. From then on, the invisible hand of the market should rule the sector, rather than the former state monopolies. ${ }^{12}$ However, alongside the impetus for reform, concerns were raised about the effect such reform might have on values important to the people of the member states, such as universal service. ${ }^{13}$ Universal service in this context refers to providing access to telecommunications in ways a "pure" free market would not."

Important literature addresses whether there should be a right to basic services like telecommunications and electricity. ${ }^{15}$ However, in relation to telecommunications in Europe in general and France in particular, the question is fairly well settled by law, and the argument is about implementation. Article 16 EC of the Treaty of Amsterdam said that:

[G]iven the place occupied by services of general economic interest in the shared values of the Union as well as their role in promoting social and territorial cohesion, the

Community and the Member States, each within their respective powers and within the

Administrative Design, 66 J. OF POL. 176, 178-82 (2004); AMY ZEGART, FLAWED BY DESIGN: THE EVOLUTION OF THE CIA, JCS, AND NSC 49-52 (1999).

${ }^{12}$ Pierre Larouche, Competition Law and Regulation in European Telecommunications 35 (2000).

${ }^{13}$ Damien Geradin, The Opening of State Monopolies to Competition: Main Issues of the Liberalization Process, in The Liberalization of State Monopolies in the European Union AND Beyond, 181, 181-183 (Damien Geradin ed., 1999); JOHANNES M. BAUER, Regulation and state ownership: conflicts and complementarities in eu telecommunications, 76 ANNALS OF PUB. AND COOPERATIVE ECON. 151, (2005); Pierre Larouche, Telecommunications, in THE LIBERALIZATION OF STATE MONOPOLIES IN THE EuROPEAN UNION AND BEYOND, 15 (Damien Geradin ed., 2000); Wolf Sauter, Universal Service Obligations and the Emergence of Citizens' Rights in

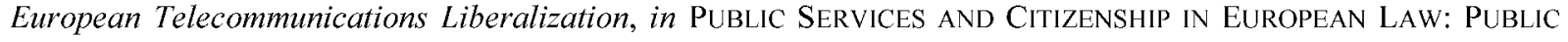
AND LABOUR LAW PERSPECTIVES, 117, 134-36 (Mark Freedland \& Silvana Sciarra eds., 1998).

${ }^{14}$ Dorit Rubinstein Reiss, Agency Accountability Strategies After Liberalization: Universal Service in the United Kingdom, France, and Sweden, 31 L. \& POL'Y 111, 118-119 (2009).

${ }^{15}$ See Sauter, supra note 13, at 120-21; Élie Cohen \& Claude Henry, Sur les Bases et l'Évolution Récente des Services Publics Industriels et Commerciaux en France et dans l'Union Européenne, in SERVICE PUBLIC, SECTEUR Public, 9, 9-10(Conseil d'Analyse économique ed., 1997); Mark Freedland, Law, Public Services, and Citizenship New Domains, New Regimes?, in Public SERVICES AND CITIZENShIP IN EUROPEAN LAW, (Mark Freedland \& Silvana Sciarra eds.,1998); Elisenda Malaret Garcia, Public Service, Public Services, Public Functions, and Guarantees of the Rights of Citizens: Unchanging Needs in a Changed Context, in PUBLIC SERVICES AND Citizenship IN EuROPEAN LAW, 57, 58-59 (Mark Freedland \& Silvana Sciarra eds., 1998); Adrienne Heritier, Market integration and social cohesion: the politics of public services in European regulation, 8 J. EUR. PUB. POL'Y 825 (2001). 
scope of application of this Treaty, shall take care that such services operate on the basis of principles and conditions which enable them to fulfill their missions. ${ }^{16}$

In the telecommunications context the European Union has officially decreed that access (though not free access) to telecommunications is an important and basic right. The Universal Service Directive states that liberalization goes hand in hand with securing the delivery of universal service. ${ }^{17}$ Section 14 then goes on to say: "The importance of access to and use of the public telephone network at a fixed location is such that it should be available to anyone reasonably requesting it." 18

The details, however, are left to the member states, and can vary substantially. ${ }^{19}$ Similarly, the decision whether to compensate the operators providing universal service for their costs has been left to the member states - within certain constraints aimed at assuring that the funding mechanism will not give the incumbent an unfair advantage. A number of European states have chosen to potentially compensate their universal service providers ("USO") and therefore evaluate USO costs. However, once the ratio between cost and compensation has been evaluated, only two countries, France and Italy, use a direct fund.

France was especially concerned about the effect of the liberalization process on public service. Public service is an important value in France. ${ }^{20}$ In addition, the previous economic tradition in France emphasized other values besides competition and free markets, including large national champions which were held in high regard, and which served the nation, sometimes even when that was contrary to their narrow economic interests. ${ }^{21}$

Under these circumstances, it was easy for France to adopt a universal service program including geographic balancing and relatively generous provisions for vulnerable customers. ${ }^{22}$ It also seemed obvious to members of the French government that fairness required compensating France Télécom for the burden placed on it by its universal service obligations. ${ }^{23}$ Since universal

16 Treaty of Amsterdam Amending the Treaty on European Union, the Treaties Establishing the European Communities and Certain Related Acts, Oct. 2 1997, 1997 O.J. (C 340) 1, 37 I.L.M. 56. For a more detailed description of the development of Universal Service in EU law and especially in relation to network services, see Stephane Rodrigues, La régulation communautaire des services publics de réseaux, vers une théorie générale de la concurrence régulée?, 44 Flux 80, (2001).

${ }^{17}$ Council Directive 2002/22, 2009 O.J. (L 108) 51.

${ }^{18}$ Directive 2002/22, supra note 17 , at 53.

${ }^{19}$ Dorit Rubinstein Reiss, Regulatory Accountability: Telecommunications and Electricity in the United Kingdom, France and Sweden (Feb. 2008) (unpublished Ph.D. dissertation, University of California, Berkeley) (on file with author).

${ }^{20}$ Schmidt, supra note 6, at 906; Cohen \& Henry, supra note 15, p. 12; DeNOIX DE SAINT MARC, LE SERVICE Public: Rapport Au Premier Ministre 17 (1997); Tony Prosser, Public Service Law: Privatization's Unexpected Offspring, 63 LAW \& CONTEMP. PROBS. 63, 75-76 (2000); Elodie Renaudin, L'évolution du Service Universel dans le Secteur des Télécommunications (2004) (unpublished DEA Droit Public des Affaires dissertation, Universite Paris x Nanterre) (on file with author), available at http://droitfil.free.fr/MemSU.PDF.

${ }^{21}$ COHEN \& HENRY, supra note 15, p. 51; Barry Owen, France, in COMPARATIVE PUBLIC ADMINISTRATION 45 (J.A. Chandler ed., 2000); Nicolas Charbit, Country Report: France, in THE LIBERALIZATION OF ELECTRICITY AND NATURAL Gas IN THE European UNION 123 (Damien Geradin ed., 2001); JABKO \& EISING, supra note 5; See MARK Thatcher, The Politics of Telecommunications: National Institutions, Convergence, And CHange In BRITAIN AND FRANCE 159-60 (2000) (noting the case of France Télécom, transferring parts of its revenue to the national treasury rather than reinvesting it in its own network). Similarly, in an interview with a member of the French Electricity Company, EDF, a member mentioned that in spite of the costs of universal service going up, the ministry did not want electricity tariffs to rise and forced EDF to keep the prices artificially low, against their business interest. Interview with EDF official, in Paris, Fr. (Jan. 11, 2005).

${ }^{22}$ Reiss, supra note $145,125-126$.

${ }^{23}$ Interview with member of the French Telecommunications Agency, ART, in Paris, Fr. (Dec. 9, 2004). 
service is an important public value, and the state wishes to provide it for the community, the cost should be shared among all users.

Accordingly, sections R. 20-31 to R. 20-34 of the Posts and Telecommunications Code established a funding mechanism for universal service. ${ }^{24}$ Here France made its first crucial policy choice. Rather than fund universal service through adding a set amount to customers' telecommunications bills (as it did in electricity, for example), ${ }^{25}$ or through adding a supplementary interconnection charge (as was done in telecommunications in Belgium), ${ }^{26}$ the government created a universal service fund, to which all operators were required to contribute (later passing the costs on to their customers). This raised complex implementation issues. The most basic task entrusted to the regulator, Autorité de Régulation des Télécommunications ("ART"), ${ }^{27}$ was to calculate what universal service cost-not an easy calculation. However, beyond the problem of calculating the cost, important questions about distributing the burden remain. Which operators will contribute? How will their share be calculated? There are several ways to do this, and any choice would be controversial, since there will inevitably be winners and losers.

Under the European directive, Universal Service costs are determined by calculating the costs of providing it minus the costs that the operator would incur anyway, i.e., comparing the costs to the operator in a situation where they have to provide universal service with a hypothetical situation in which they would not have to provide it. However, that still leaves a lot to be determined. The costs assessed for universal service in France can be grouped under five headings:

1. Rebalancing France Télécom's tariffs until 2000, as a temporary measure.

2. The costs of geographic balancing-i.e., assuring that all customers, regardless of where they live, pay the same maximum price for fixed access and fixed voice telecommunications service, so that rural customers and customers living in remote locations (where the costs of providing services are higher) will not pay substantially higher sums than those in urban areas.

3. Social tariffs - special low tariffs for "vulnerable customers," who cannot afford full price.

4. The costs of providing public payphones even where it is not profitable.

5 . The costs of publishing an annual free paper directory and running a vocal directory service at a reasonable price.

While the calculation of the costs for items 2 through 5 was done in a fairly straightforward (although quite lengthy) way using measured data, for item 1 France used a very complicated formula which required both estimated and measured data. France Télécom collected the measurable data with some accuracy, but the basis for the estimation was

\footnotetext{
${ }^{24}$ Loi 97-475 du 13 mai 1997 Code des Postes et Communications Electroniques [Law 97-475 May 13, 1997 Posts and Telecommunications Code], Journal OfFiciel DE la RÉPublique FrançAise [J.O.] [OfFicial GazeTte OF FRANCE], May 14, 1997, Art. R20-31 - R20-34.

${ }^{25}$ Interview with former member of the French Energy Regulation Commission, CRE, in Fr. (Jan. 21, 2005).

${ }^{26}$ Interview with member of the French Telecommunications Agency, ART, in Paris, Fr. (Dec. 9, 2004).

${ }^{27}$ The regulator of telecommunications in France used to be l'Autorité de régulation des télécommunications, known as the ART; however, following the regulatory package of 2003 the agency became the Autorité de régulation des communications electroniques et des postes, known as ARCEP. I am referring generally to ART since at the time of the events surrounding the EU decision, it was the ART, and I think that consistency in using the name will prevent confusion.
} 
challenged successfully by the European Commission before the ECJ. ${ }^{28}$ The calculation of all five components is complex, lengthy, and requires masses of data, supplied annually by the universal service supplier, France Télécom (most of the data is subject to audits annually conducted by the regulator, ART). The entire process is work intensive and requires a high level of expertise.

France initially decided to include all licensed operators, including mobile operators, but not Internet Service Providers ("ISP"), as contributors. The requirement that mobile operators share in paying for the costs for only 1997 was struck down by the ECJ's decision, but those operators were not absolved from contributing to the costs of universal service in subsequent years. France calculated the burden on each operator according to the volume (in terms of minutes) of network usage; it later decided to charge each operator by revenue, seeing revenue as a more equitable measure. France Télécom was also a contributor, and in fact paid the major share (under both systems).

In addition, during the first few years France used several transitional arrangements. For example, instead of calculating some of the components of the formula for the first two years, where the numbers were not being collected yet, it used flat rate estimates based on numbers used by other European countries.

\section{B. WhO IS REQUIRED TO PAY UNIVERSAL SERVICE? ${ }^{29}$}

As explained above, the costs of universal service are mostly spread between France's fixed and mobile operators. Who are these operators?

The main provider of universal service is the French incumbent, France Télécom, currently only partly owned by government (45.3\%), but strongly influenced by it in more than one way. The head of the firm was usually a figure with substantial political connections (a former president of France Télécom, Thierry Breton, had then become the Minister for industrial affairs and is known to be a friend of Rafarrin, the former Prime Minister, ${ }^{30}$ and his successors both the chairman of the board and the CEO - are also well connected). ${ }^{31}$ In addition, many agency members have worked, for France Télécom, as have many members of other companies

\footnotetext{
${ }^{28}$ The rebalancing tariff, the first component, is calculated using the following formula: $\mathrm{C}=12 \times(\mathrm{Pe}-\mathrm{P}) \times \mathrm{N}$ where $\mathrm{Pe}$ is the estimated monthly subscription charge after rebalancing; $\mathrm{P}$ is the actual subscription charge at the time and $\mathrm{N}$ is the number of customers without special contracts. This information is taken from the ECJ decision. Case C146/00, Commission v. France, 2001 E.C.R. I-9767 [hereinafter Case C-146/00].

${ }^{29}$ This discussion is largely based on the data collected for my dissertation, Dorit Rubinstein Reiss, Regulatory Accountability: Telecommunications and Electricity in the United Kingdom, France and Sweden (Feb. 2008) (unpublished Ph.D. dissertation, University of California, Berkeley) (on file with author).

${ }_{30}$ In the words of one Frenchman in an informal conversation, 'ils se tutoient', or they address each other using the familiar 'tu' address.

31 Didier Lombard, Chairman of Strategy Committee, FRANCE TELECOM, http:/www.orange.com/en_EN/group/governance/board-directors/index.jsp (last visited Mar. 25, 2010). From the biography of Didier Lombard, appointed CEO and then chairman of the board of directors of France Télécom after Breton: From 1988 to 1990, he was the Scientific and Technical Director at the Ministry of Research and Technology. From 1991 to 1998, he was General Manager of Industrial Strategy at the Ministry in charge of Economy, Finance and Industry. He is Officier de la Légion d'honneur and Commandeur dans l'Ordre National du Mérite. Id.; Stephane Richard, Chief Executive Officer, FRANCE TELECOM, http:/www.orange.com/en_EN/group/management/members/Stephane_Richard.jsp (last visited Mar. 25, 2010). In February 2010, Stephane Richard was appointed as CEO; he graduated from the prestigious Ecole Nationale d'Admnistration, served in many high positions in industry and in many high level public service posts, including Chief of Staff for the French Minister for the Economy, Industry and Employment (2007-2009). Id.
} 
or of other actors who work in the telecommunications field. However, France Télécom did not just receive funding for universal service, it also paid into the fund, both as "France Télécom" and for its mobile operator, Orange, and since it was - by any criteria - still the largest operator, it paid the largest share. A member of France Télécom described this as "we take the money out of our right pocket to pay into our left pocket." 32

In addition to France Télécom, France had three substantial mobile operators: Orange, which is a part of the France Télécom group, SFR (Société Française De Radiotéléphone) and Bouygues Télécoms.

In 2008, SFR merged with the fixed operator Neuf Cegetel, and therefore at that point also owned a fixed network:

"With 19.7 million mobile customers and 3.9 million high-speed Internet customers, the new SFR - created from the merger between SFR and Neuf Cegetel* - is the leading alternative mobile and fixed-line operator in Europe, offering solutions tailored to the needs of individuals, companies and operators." 33

SFR is a large company with years of experience and substantial sophistication. It is also owned by large companies. The Vivendi group mostly holds SFR. ${ }^{34}$ Vivendi is a large multi national company, self-described as "a world leader in communications and entertainment." 35 SFR is clearly not a small startup without business savvy or ability to defend itself.

The other mobile operator, Bouygues Telecoms, belongs to the Bouygues group, a powerful economic conglomerate with subsidiaries in the construction area and communications area in France and worldwide. ${ }^{36}$ Once again, it is by no means a start up or a company without business experience.

The fixed operators in France include, among others, Belgacom, Belgium's incumbent, BT France - a subsidiary of the British incumbent - and other large firms. ${ }^{37}$ There are, of course, small startups as well, but many of the cases, as a glance at the list in Appendix II demonstrates, were brought by large and sophisticated operators.

\footnotetext{
${ }^{32}$ Interview with member of France Télécom, in Paris, Fr. (Dec. 22, 2004).

${ }^{33}$ SFR, VIVENDI, http://www.vivendi.com/vivendi/SFR,952 (this was the text there when last visited Mar. 10, 2010; it has since been changed and now reads: ": SFR is a 56\% subsidiary of Vivendi. With more than 20 million mobile customers, 4.6 million broadband Internet customers and 6,248 million euro in revenues for the first half of 2010 , SFR is Europe's leading alternative operator and France's leading alternative telecommunications operator. SFR is an integrated operator, owner of its mobile and fixed-line infrastructures, able to respond effectively to the needs of all customers - the general public, professionals, businesses and other operators.". This change supports rather than undermines the point made - that SFR is not a small start up but rather a part of a large and experienced company).

${ }^{34}$ This information is taken from Vodafone's own site, where it lists its holding in other telecommunications company. Available

at: http://www.vodafone.com/start/investor_relations/structure_and_management/subsidiaries.html, (last visited Mar. 10, 2010).

35 Press Release, Vivendi, Vivendi to Emphasize its Position as a World Leader in Communications and Entertainment with its New Advertising Campaign (Mar. 9, 2009), available at http:/www.vivendi.com/vivendi/IMG/pdf/PR090309_CAMPAGNE_PUBLICITAIRE.pdf.

36 Presentation of the Bouygues Group, BOUYGUES, $\bar{h}$ ttp://bouygues.com/en/group/presentation/presentation-of-thebouygues-group/presentation-of-the-bouygues-group/ (last visited Mar. 10, 2010).

${ }^{37}$ Les Opérateurs Télécoms, ARCEP, http://www.arcep.fr/index.php?id=9320 (last visited Mar. 10, 2010).
} 


\section{THE ECJ DECISION STORY-FRENCH RESISTANCE}

To read the ECJ's decision and the very few relevant scholarly references to the decision, ${ }^{38}$ universal service is the story of French resistance to the European Union's desire to create real competition in the market. France, when creating its system for funding universal service, has in design and implementation skewed the funding system to benefit France Télécom at the expense of new operators. However, the European Commission refused to let France get away with this. The most dramatic battle began in 2000, when, after repeated communications with France did not lead to corrective action, the European Commission filed a complaint with the ECJ against the French universal service funding system.

On December 6, 2001 the ECJ justified the commission's misgivings and ruled against France, ${ }^{39}$ finding that its system for funding universal service violated the European directives. ${ }^{40}$ The findings can be grouped under four headings. First, inflating the costs of universal service, thereby benefiting France Télécom at the expense of new entrants. For example, ECJ criticized France's inclusion of "red list" costs - the list of customers whose name will not appear in the directory, non-listed customers - as part of the calculation. Conversely, France did not calculate the "intangible benefits" that France Télécom will receive from being the universal service provider. ${ }^{41}$ France was also charged with "estimating up" in several cases-i.e., evaluating costs beyond what was the rate in other countries. Second, the commission strongly criticized several methodological "shortcuts" used by France to calculate the costs of the first years. France chose not to calculate some of the components in its formula, instead using estimates based on the practices in other countries as shortcuts. For example, it set the net cost of non-profitable subscribers at one percent of total turnover; and the geographical component at three percent of turnover. It also calculated the initial cost of a non-profitable household as if all households were non-profitable, claiming it is unable to identify those that were profitable before the balancing of the tariffs. The claim against the method was that the French calculations lacked transparency, both because some of the components of the formula were estimated based on comparisons with other countries without explanation of the specific numbers arrived at, and because French government did not submit information it was required to provide under the law. Finally, the Commission and France disagreed on the interpretation of several provisions of the directive. For example, the commission - and the Court - interpreted the directive as requiring the tariffs, if not completely rebalancing them by 2000 , at least a detailed timetable. The French Government did not interpret the directive to require such a timetable.

Finding against the French system, the ECJ, under this version of the story, bravely forced the rogue state to correct its problematic practices. Indeed, ART's reevaluation after the ECJ's decision showed substantial reductions in the assessed amount of costs of universal service and the amount operators had to pay to the fund. The amount for 1998 went down from

\footnotetext{
${ }^{38}$ Colin D. Long, Global Telecommunications Law and Practice (2004); Renaudin, supra note 20, at 36-37; Michel Berne, Telecommunications Universal Service in France, 10 INFO 121, 125-26 (2008).

${ }^{39}$ Case C-146/00.

${ }^{40} I d$. A detailed description of the claims and the ECJ decision is attached here as Appendix I.

${ }^{41}$ Britain, for example, did consider their incumbent's - British Telecoms, now BT - in their analysis of universal service costs. This led the British regulator, at the time, Oftel, the Office of Telecommunications, to conclude that the benefits cancel out the costs and BT does not deserve to be reimbursed. Dorit Rubinstein Reiss, Regulatory Accountability: Telecommunications and Electricity in the United Kingdom, France and Sweden (Feb. 2008) (unpublished Ph.D. dissertation, University of California, Berkeley) (on file with author).
} 
4,374 million francs before the ECJ's decision to 1,806 million francs after it; the amounts for 1999 went down from 1,646 million francs before to 725 million francs after the decision. ${ }^{42}$

However, even with the ECJ's brave interference, the French system was not completely fixed, and constant vigilance was required. Luckily, the operators competing with France Télécom took the burden on themselves. Accordingly, when the French regulator continued to be recalcitrant, the association of French operators-AFORST - filed another complaint with the commission. ${ }^{43}$ Similarly, operators brought several suits in the French courts against France, demanding that the system be corrected.

This version of the story can be supported by other examples of tensions between the commission and France over France's protection of national champions, and scholarship showing the French tendency to strongly support such champions. ${ }^{44}$ It can also be supported by focusing on ideological differences in values between France and the commission. ${ }^{45}$ Universal service is important to the French. The commission, on the other hand, has been promoting and supporting liberalization for years. It values open competition and the market. The definition of universal service in the EU directive surrounds it with many caveats. The commission that enforces it does not encourage it. The ECJ, as part of the EU institutions and as an institution enforcing treaties that place great weight on open competition, may be more sympathetic to the operators' view than to the French desire to assure generous compensation of the universal service provider. ${ }^{46}$ However, this is not the only possible story.

\section{An ALternative Story: New Entrants v. Universal SERVICE Funding}

A very different story can be told about the struggle around universal service funding. While the two stories do not directly contradict each other, the second story suggests different cautions, many of which figure prominently in the United States regulation of the sector.

Under the second story, when transposing the universal service system into domestic law, the French government created a mechanism to properly fund universal service. That mechanism will allow the level of services the French government wanted to secure and assure that France Télécom will not bear the costs of universal service on its own. If France Télécom is to operate

42 This recalculation of the amount after the ECJ's decision is taken from: Autorité de régulation des télécommunications (2002) Décision 02-329, Avril 23 2002, "Proposant les évaluations rectificatives du cout du services universel et les contributions des operateurs pour les années 1997 a 1999 et proposant une modification de l'évaluation prévisionnelle du cout du service universel et des contributions des operateurs pour l'année 2002. Can be found on the regulator's site, at: www.arcep.fr/.

${ }^{43}$ Renaudin, supra note 20 , at 36.

${ }^{44}$ Frank S. Benyon Direct Investment, NATIONAL Champions AND EU TREATy Freedoms: From MaAstricht TO LISBON 96 (2010); Ian Bartle, When Institutions No Longer Matter: Refrm of Telecommunications and Electricity in Germany, France and Britain, 22 J. PUB. POL'Y 1, 7 ( 2002) Volker Schneider, Institutional Reform in Telecommunications: The European Union in Transnational Policy Diffusion, in TRANSFORMING EUROPE: EUROPEANIZATION AND DOMESTIC CHANGE 60, 77 (Maria Green Cowles et al. eds., 2001); Bartle, supra note 4 at 7; Thomas Kiessling \& Yves Blondeel, The EU Regulatory Framework in Telecommunications: A Critical Analysis, 22 Telecomms. Pol'y 571, 572-92 (1998); Sebastian Eyre \& Nick Sitter, From PTT to NRA: Towards a New Regulatory Regime?, in EUROPEAN TELECOMMUNICATIONS LIBERALISATION 39, 48-50 (KJELL A. ELIASSEN \& MARIT SJØVAAG eds., 1999). But for a different vision that sees Europe and national governments as cooperating in liberalization. Thatcher, supra note 5.

45 Nicolas Jabko, Playing the Market: A Political Strategy for Uniting Europe, 1985-2005 160-63 (2006).

${ }^{46}$ I am grateful to Frederic Carteron who, though his analysis was different than the one above (and one I hope he publishes separately), raised the point of differing values. 
as any other firm competing in the market, forcing it to solely fund the non-profitable services government thinks should be provided, it would be at a disadvantage compared to its competitors. Rather, costs should be part of the cost of doing business in France and shared in a way that puts all market players in the same situation. Accordingly, the mechanism requires other operators to contribute to a universal service fund that will cover the costs. ART calculates the costs according to criteria detailed by the legislature. The costs are apportioned among operators according to an objective formula based on the advantages they get from the system. While France Télécom, the monopoly that receives the highest advantages, will bear the bulk of the costs, other operators will bear a proportion of the costs according to their profits. France designed the system according to its best understanding of what was allowed under European Union law, although it did place a value on compensating France Télécom for real costs it incurs in providing what is, in effect, a social service. ${ }^{47}$

The competing operators are for-profit companies that do not share the French government's commitment to universal service. Even if they may be sympathetic to universal service in principle, they naturally want to minimize their share, or not pay it. Faced with large annual bills for universal service, they have a strong incentive to mobilize and fight to undermine the funding system. Initially, they took the fight to Europe. After the ECJ had its say finding much to fault with the French system and the French regulator fixed the system accordingly, they had to find a different way to avoid the costs. The telecommunications operators started challenging every decision of the French regulator in the courts-whether or not such a challenge had merit and realistic chances of success.

Accordingly, this view sees the ECJ decision in a different way. The source of the EU action is, in this view, a result from the operators' objection to paying for universal service. Specifically, it stemmed from complaints lodged by two associations of operators, l'Association Française des Opérateurs Privés en Télécommunications ("I'AFOPT") and l'Association des Opérateurs de Services de Télécommunications ("l'AOST"). ${ }^{48}$ Accordingly, the motivation of the process is not in the commission's efforts to force France to tow the line, but in the operators' unhappiness with having to pay.

This view also emphasizes another direct consequence of the ECJ decision. Aside from lower universal service costs assessed against the operators, the decision added substantial costs and upheavals to a system that was not easy to implement to start with. The ECJ decision sent the Ministry and ART back to the drawing board, to redesign the funding mechanism according to the ECJ's requirements and to redo the work done for the first years, 1997-1999 at the least. A year and a half later, in April 2002, ART suggested modifications. ${ }^{49}$ The modifications deviated from ECJ's decision in a few details, where ART saw the ECJ's decision as being based on a misunderstanding of the situation. For example, ART explains in its decision that while the ECJ criticized ART for not including a detailed breakdown of the calculation of the element $\mathrm{Pe}^{50}$ in its formula, ART believed that a detailed breakdown was actually included. However, for the most part ART put in place substantial changes in the system, cooperating with the ECJ decision. Following ART's work, on July 11, 2002 the minister enacted a regulation ("arrêt") 51 setting the

\footnotetext{
${ }^{47}$ Interview with member of the French Telecommunications Agency, ART, in Paris, Fr. (Dec. 9, 2004); Interview with member of France Télécom, the French telecommunications incumbent, in Paris, Fr. (Dec. 22, 2004).

${ }^{48}$ Autorité de régulation des télécommunications, supra note 44.

${ }^{49}$ Autorité de régulation des télécommunications, supra note 44.

${ }^{50}$ Which represents the standard monthly line rental charge of reference in the formula, i.e. the theoretical line rental charge that would be achieved if complete rebalancing took place.

${ }^{51}$ The French system, where the executive enjoys substantial powers to legislate as well as to create rules, has more
} 
sums for 1998-1999 as well as for 2002 according to ART's recommendation. Shortly after that, ART sent out individual decisions setting each operator's contribution for 2002. Later on it also sent out the individual decisions regarding 1998-1999.

At this point the operators started using the domestic courts to combat the requirement that they share in paying the cost for universal service. In the years following the ECJ decision many cases were brought against the regulator. Some had merit, but many were brought without any attempt to appeal to the minister, ignoring a basic procedural requirement embedded in the French Code of Administrative Justice.

The first case decided was brought by the company Tiscali, objecting to the assessment of over three million Euros for its universal service contribution in 2002. Tiscali emphasized its financial difficulties and the fact that the law was not yet changed in accordance with the ECJ's decision.

The court made two important rulings. ${ }^{52}$ As a general matter it stated that funding universal service was an important policy objective for which the minister was responsible. Since the matter could be urgent, the minister had, in principle, the right to enact temporary decrees setting amounts to be paid even before the law was changed in accordance with the ECJ decision. However, the court ruled that such decisions must be made in a transparent way. The arrêt in this case was not published, nor were the operators notified about it before receiving their apportionment - therefore it was void. While the court acknowledged that the operator had a case in this instance, it made it clear that the operator's main contention, that no costs can be placed on operators until a new decree ${ }^{53}$ is passed, was wrong. The Minister and ART can require Operators to contribute to the universal service fund before the law is amended according to the ECJ decision, as long as the process is transparent and the ruling observed.

The Tiscali case was the opening shot, followed by many other cases. In 2005 alone, the Conseil d'État decided 15 cases regarding ART's decisions about universal service for the years up to 2002. In an interview with a member of ART, he said that almost every decision of the regulator was attacked in the courts. ${ }^{54}$ In $2002-2006$, at least one operate, often more, systematically attacked every decision setting the rules used to calculate the costs for the past year and the final calculation and compensations balances for that year. ${ }^{55}$

Out of the 15 cases decided in 2005, 10.5 of the complaints against ART's price determinations were rejected by the court for not requiring "reclamation" from the minister - in more familiar American parlance, for non-exhaustion of administrative remedies. ${ }^{56}$

than one kind of rule/regulation. An arrêt is a relatively low-level - i.e., specific, and subject to other types of regulations - implementation decree.

${ }^{52}$ CE Sect., June 18, 2003, Societe Tiscali Telecom Req. No. 250608, available through www.legifrance.com (last visited April 29 2011).

${ }_{53}$ A decree is a higher level general regulation.

${ }^{54}$ Interview with member of the French Telecommunications Agency, ART, in Paris, Fr. (Dec. 9, 2004).

${ }_{55}^{5}$ Id. A complete list of cases, with a (very) short description of each, is attached as Appendix II.

${ }^{56}$ For several of these the complaint against the decree was acknowledged as justified under Tiscali, but the ART's decision could not be addressed because the company in question did not address the minister beforehand. Therefore, only part of the complaint was rejected for non-exhaustion. See, e.g., CE Sect., Apr. 1, 2005 , Societe 9 Telecom Req No 250609 available through www.legifrance.com (last visited April 29 2011).; CE Sect., Apr. 1, 2005, S.A. Bouygues Telecom, Req. No. 250572, available through www.legifrance.com (last visited April 29 2011).; CE Sect., Dec. 5, 2005, S.A. Bouygues Telecom, Req. No. 257683 available through www.legifrance.com (last visited April 29 2011). The principle that before taking an administrative agency to court an actor must exhaust - make use of - the procedures to challenge the decision offered by the agency is a long standing one in American administrative law. See, for example, Sims v. Apfel, 530 U.S. 103, 108-110, 120 S.Ct. 2080 2085-2087, 147 L.Ed.2d 
Article R. 772-2 of the Code of Administrative Justice states, in the relevant parts: "Les requêtes mentionnées au deuxième alinéa de l'article précédent doivent être précédées d'une réclamation adressée à la personne morale qui a établi la taxe. . . . ${ }^{57}$ Which translates to: The demands (requests) mentioned in the second paragraph of the previous article ${ }^{58}$ must be preceded by an appeal (reclamation) to the actor esablishing the tax. ${ }^{59}$

In other words, the law clearly requires an application to the minister against the assessment made against the operator. In spite of this clear requirement, the cases were filed without any attempt by the companies to address their concerns to the regulator or minister beforehand. As described above, the companies are sophisticated large actors, including French branches of other European incumbents, such as Teleitalia, the Italian incumbent, and telecommunications companies which belong to large, sophisticated French business conglomerates, such as Bouygues Telecoms and SFR. They are well acquainted with French law, or at least, they can hire lawyers who are. It is unlikely the lawyers missed the non-exhaustion requirement described above. The impression is that cases are being brought to the Conseil d'État even if operators know the case will be rejected. The question is, why.

One explanation is that the operators, rightly or wrongly, expect the minister to automatically side with the regulator, and do not want to waste time on a futile appeal. This may be true, but they must know that not approaching the minister will harm their chances at appeal. Another explanation is needed.

In a system where decisions need to be made every year and where the decisions require a high level of expertise and intensive labor, recurring appeals can be very disruptive. The Conseil d'État did not overrule any of the cases on substantive grounds; but it annulled several of the decisions that were made before the passage of the 2003 decree on procedural grounds. It did so in decisions that came down in 2005, after the decree was in place. That means the companies could hope to delay the process and/or recoup some of the costs. The courts could be used to delay and weaken the implementation of the universal service funding mechanism.

\section{Discussion}

The first question is which version of the story is more convincing. The first story fits views of the French economy as based on support of national champions and opposition to the liberalization process. ${ }^{60}$ It can fit with previous tensions between France and the European Commission on liberalization, and it is supported by the dramatic decrease in costs of universal service charged to the operators compared to the costs before the ECJ decision. However, the second version seems more convincing.

80 (2000) At the state level see Project: State Judicial Review of Administrative Action, 43 ADMIN. L. REV. 571 , 661-679 (1991).

${ }^{57}$ CODE DE JUSTICE ADMINISTRATIVE art. 772-2. The second paragraph in the article has been omitted.

${ }^{58}$ Demands related to taxes and other impositions that fall under the administrative jurisdiction. See id.

${ }^{59}$ The translation is my own.

${ }^{60}$ Élie Cohen \& Claude Henry, Sur les Bases et l'Évolution Récente des Services Publics Industriels et Commerciaux en France et dans l'Union Européenne, in SERVICE PUBLIC, SECTEUR PUBLIC (Conseil d'Analyse économique ed., 1997); Sebastian Eyre \& Nick Sitter, From PTT to NRA: Towards a New Regulatory Regime?, in European Telecommunications liberalisation 39 (KJell A. Eliassen \& Marit SjøvaAG eds., 1999); Rainer Eising \& Nicolas Jabko, Moving Targets: National Interests and Electricity Liberalization in the European Union, 34 COMP. POL. STUD. 742 (2001); Mark Thatcher, Winners and Losers in Europeanisation: Reforming the National Regulation of Telecommunications, 27 W. EUR. POL. 284 (2004) [hereinafter Thatcher 2004]. 
The realities of universal service are such that the benefits to France Télécom from increasing the funding are not very great. France Télécom pays the largest share of universal service costs. The legal framework allows other operators to provide certain parts of the universal service too. In particular, companies can offer social tariffs-reduced tariffs to individual groups - and be reimbursed for their loss from the universal service funds. For a time, at least one company took advantage of that option. ${ }^{61}$ Therefore, increasing universal service funding is not a dramatic help for France Télécom. The French government's interest in inflating the costs of universal service to support the incumbent is not as great as it might appear at first blush. ${ }^{62}$

But the more important evidence supporting the second story is the continuing and recurrent appeals to the courts. The heavy use of the domestic courts after the ECJ decisionespecially bringing cases doomed to failure - suggests reluctance to pay the contribution, whatever the amount. Even winning regularly, the need to constantly defend its behavior in court adds to the agency's burden and may lead it to be very cautious in its decision-making. ${ }^{63}$

Judicial review of administrative agencies seeks to prevent abuses and offer a counter to agency professional biases. ${ }^{64}$ However, as acknowledged by scholars, judicial review carries its own risks. ${ }^{65}$ One of those risks, though not the only one, is the ability of regulatees to use courts to delay and undermine regulation they are unhappy with. The idea that courts can be used to delay implementation of regulation is not new. ${ }^{66}$ However, dealing with the problem presents a constant challenge, and few real solutions have been suggested. The problem is that the companies involved have a legitimate interest to defend. The operators need a way to protect their rights and prevent abuses by the regulators, as well as to solve disputes with them - and the courts are an acknowledged mechanism to handle these kinds of issues. ${ }^{67}$ In the French case especially, companies had good reasons to worry about the regulator being subservient to France Télécom, since there were close ties between many members of the regulators and France Télécom-specifically, many members of the regulator were trained in the École Nationale

61 The company Kertel provided social tariffs between 2000-2002. See Autorité de régulation des télécommunications (2000) Décision 00-459, May 17 2000, relatif a la demande de la société Kertel de proposer tarifs sociaux; Autorité de régulation des télécommunications (2002) available at www.arcep.fr. (recommeding that Kertel be allowed to provide social tarifs); Décision 02-308, April 23 2002, relatif au retrait pour l'année 2002 de la société Kertel de la prestation de «tarifs sociaux » available at www.arcep.fr. (recommending that Ketrel be allowed to stop providing social tarifs).

${ }^{62}$ Though it is a help, and could make it harder for a new competitor to successfully compete if they do indeed pass on their costs to the consumer through higher prices.

${ }^{63}$ On negative consequences of heavy litigation on agency behavior see EUGENE BARDACH \& ROBERT A. KAGAN,

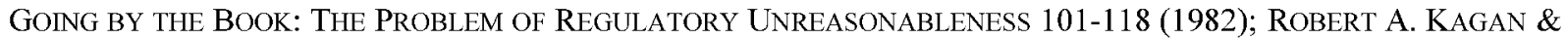
leE Axelrad, Regulatory Encounters: Multinational Corporations and American Adversarial LEGALISM 389-400 (2000).

${ }^{64}$ Martin Shapiro, Judicial Delegation Doctrines: the US, Britain, and France, 25 W. EUR. POL. 173 (2002).

${ }^{66}$ Tom Burke, On the Rights Track: the Americans with Disabilities Act, in COMPARATIVE DiSADVANTAGES? Social Regulations and American Adversarial Legalism 242, 244 (Pietro Nivola ed., 1997); CHRISTOPHER F. EdLEy JR., AdMINISTRATIVE LAW: RETHINKING JUdiCIAL CONTROL OF BUREAUCRACY 237-244 (1992); MARTIN Shapiro, Who Guards the Guardians?: Judicial CONTROl of AdMinistration 128-134 (1988); RoBERT A. KAGAN, ADVERSARIAL LEGALISM: THE AMERICAN WAY OF LAW 29-32 (2001).

66 Rebecca Beynon, The FCC's Implementation of the 1996 Act: Agency Litigation Strategies and Delay, 53 FED. Comm. L.J. 27 (2000); Thomas O. McGarity, The Courts and the Ossification of Rulemaking: A Response to Professor Seidenfeld, 75 TEX. L. REV. 525 (1997); KAGAN, supra note 66 at 225; STUART A. SCHEINGOLD, THE Politics of Rights: Lawyers, Public Policy, and Political Change 145-46 (1974).

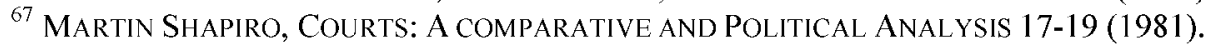


Supérieure des Télécommunications (now Telecom Paris Tech), previously funded by France Télécom, or worked for the company before being members of the regulator. ${ }^{68}$ Therefore, a mechanism for defending their rights is justifiably important to these companies.

On the other hand, the companies also have good reasons not to accept the system of funding universal service. From the point of view of the new entrants, avoiding costs they do not have to bear is part of their "job"- they are corporations judged by the amount of money they make for their shareholders, and fighting to establish themselves in a new market. Even if they agree with the idea of universal service in principle, there is no reason for them to want to pay for it if they can avoid or minimize costs - a classic free rider situation. As sophisticated strategic actors they know how to use to their advantage all the mechanisms in place, including the courts. The problem, then, is how to balance the new entrants' legitimate interest in protecting their rights while minimizing their ability to abuse the system.

One alternative is to use judicial review doctrines to balance those interests, especially in the case of the Conseil d'État. The Conseillers d'État have been trained as civil servants and specialize in handling administrative cases. Furthermore, some members of the Conseil fill important roles in the public service. ${ }^{69}$ They can be trusted to understand the realities of administration and create appropriate doctrines.

The problem with this solution is not the inability of the Conseil d'État to handle the cases before it, but the way the court is used in this area. It is litigation itself, not how cases are decided, that diverts resources to handling cases, and has the potential to cause delay and uncertainty. $^{70}$

Another solution is to impose substantial costs. Access to the Conseil d'État is in fact limited by the risk of the loser having to pay costs, including lawyers' fees. ${ }^{71}$ In some of the cases below, though not in many, costs have already been awarded to the government; however, those costs were clearly not enough to deter since they are not very high. One way to reduce problematic lawsuits is for the Conseil d'État to use its powers to award higher levels of costs"punitive" costs-where appropriate. The concern is that such a power may deter suits that should be brought - i.e., have too much of a chilling effect. The judges' expertise may justify entrusting them with such power. On the other hand, since the Conseil d'État does have very close ties to the administration, on the face of it, concerns may be raised about it using that power to protect the government. However, the Conseil d'État enjoys a high level of respect and is seen as independent, certainly not as being hand in glove with the government, ${ }^{72}$ it can safely use its powers to impose costs without much risk of provoking undue criticism. Yet another possible way around the problem is to design the regulatory system to reduce incentives to use the courts as a delay tactic.

The French experience can act as a deterrent to other countries-European or not-who want to fund universal service. Since no sane regulator wants to spend substantial amounts of time in the courts, and since in addition to the complexity of setting the initial contribution

\footnotetext{
${ }^{68}$ Interview with member of France Télécom, the French telecommunications incumbent, in Paris, Fr. (Dec. 22 , 2004). That is not to say the regulator does work for France Télécom's interests - but it could look that way.

${ }^{69}$ L. Neville Brown \& JOHN S. Bell, FrenCh Administrative Law, 63 (5th ed. 1998); YVES RoBineau \& DidiER TRUCHET, LE CONSEIL D'ETAT (1994).

${ }^{70} \mathrm{KAGAN}$, supra note 66, vii, 13-14.

${ }^{71}$ Generally true for many civil law countries. See UGo A. MatTei, ET AL., Schlesinger's Comparative Law: CASES, TEXTS, MATERIAls 691-92 (Foundation Press, 7th ed. 2009).

${ }^{72}$ Roger PERrot, InSTITUtions JudiCIAIRES 35 (11th ed. 2004); JEAN VinCENT ET AL., InSTITUTIONS JUdiCIAIRES: ORGANISATION, JURIDICTIONS, GENS DE JUSTICE 82-84 (5th ed. 1999).
} 
amounts the French system led to a very high level of litigation, others may hesitate to follow their lead. In fact, no European country besides France and Italy adopted a direct funding mechanism. ${ }^{73}$

France's difficulties with its universal funding mechanism support funding the universal service through some means other than a special fund. One way would be a direct addition to customers' bills - in which case the costs would be directly passed on to consumers, as is done by the French electric utilities; transaction costs might be reduced in this case. Another is adding additional charges through one of the other funding schemes, such as interconnection prices. A fund, where the operators are directly charged large concentrated sums once a year, makes them feel the loss much more. Since it is a direct cost and is strongly felt the operators are likely to mobilize to fight it. As has been observed by scholars, a burden on a concrete, concentrated group is much more likely to generate resistance than a burden on a diffused group. ${ }^{74}$

\section{CONCLUSION}

It may be tempting to see the French experience as a case of an anti-market state trying to impose costs on new entrants in favor of its former state monopoly. That it is not the only way in which the struggle around the costs of universal service can be seen. Surprisingly-or unsurprisingly - the French experience in these cases mirrors developments in the United States where sophisticated companies use courts to limit regulation. However, the European institutions, accustomed to viewing the French system as a "dirigist" institution willing to bend and avoid the law to support its national champions, are not sensitive to the other side of the equation, new entrants' struggle to avoid handling of cases like the one brought to the commission.

In addition, in this case the opening of the market directly led to an increase in litigation, mirroring Kagan's predictions for Europe. ${ }^{75}$ Litigation around universal service is now a fact of life for ART. Both it and the government should consider how to minimize the problems it creates while safeguarding the legitimate interests of the companies involved.

${ }^{73}$ Though some of them provide some funding to universal service indirectly through their interconnection tariffs. See Thomas Kiessling \& Yves Blondeel, The EU Regulatory Framework in Telecommunications: A Critical Analysis, 22 TELECOMMS. POL'Y 571 (1998).

${ }^{74}$ See, e.g. James Q. Wilson, Political Organizations 308-14 (1973); R. Kent Weaver, The Politics of Blame Avoidance, 6 J. PUB. POL'Y 371, 373-74 (1986).

${ }^{75}$ Robert A. Kagan, Should Europe Worry About Adversarial Legalism?, 17 OXFORD J. LEGAL STUD., 165, $172-75$ (1997). 


\section{APPENDIX I: ECJ'S DECISION—COMMISSION'S COMPLAINTS, FRANCE'S RESPONSES, AND THE ECJ'S CONCLUSIONS}

\section{First Complaint}

\begin{tabular}{|l|l|l|}
\hline Commission's claims & France responses & Decision \\
\hline Requirement to contribute to & $\begin{array}{l}\text { Article 4c does not require not } \\
\text { universal service in 1997 has } \\
\text { charging for 1997. There is no } \\
\text { no basis in community law } \\
\text { express link between } \\
\text { since FT was still a monopoly. } \\
\text { abolishing the monopoly and } \\
\text { Costs can only be refunded if } \\
\text { funding universal service. }\end{array}$ & $\begin{array}{l}\text { holephony there was no unfair } \\
\text { burden if it had to bear the full } \\
\text { cost of the universal service } \\
\text { obligations. }\end{array}$ \\
$\begin{array}{l}\text { is is an unfair burden; that } \\
\text { monopoly. }\end{array}$ & & \\
\hline
\end{tabular}

\section{Second Complaint}

\begin{tabular}{|l|l|l|}
\hline Commission's claims & France responses & Decision \\
\hline $\begin{array}{l}\text { France did not rebalance its } \\
\text { tariffs before } 1 / 1 / 1998 \text { and did } \\
\text { not send a detailed time line. It } \\
\text { put in the law that the } \\
\text { balancing will be complete } \\
\text { before } 31 / 12 / 2000 \text { but did not } \\
\text { send a detailed timetable. }\end{array}$ & $\begin{array}{l}\text { Disagree that there needs to be } \\
\text { enough under the directive, } \\
\text { and they have that. }\end{array}$ & $\begin{array}{l}\text { The law requires that } \\
\text { rebalancing must be achieved, } \\
\text { and the subscription tariff } \\
\text { must be equal to it both } \\
\text { based on costs. Undercutting } \\
\text { the balancing tariff is } \\
\text { unjustified. Balancing was not } \\
\text { achieved, even if the } \\
\text { difference was small, and the } \\
\text { French Government should } \\
\text { submit the timeline. }\end{array}$ \\
\hline
\end{tabular}

Third Complaint: method of calculating next costs

\begin{tabular}{|l|l|l|}
\hline Commission's claims & France responses & Decision \\
\hline $\begin{array}{l}\text { Profitable household } \\
\text { subscriptions were included: } \\
\text { profitable-if cost less than }\end{array}$ & $\begin{array}{l}\text { Ok to provide services to } \\
\text { customers which can be } \\
\text { provided at a loss or condition } \\
\text { revenues. Need to determine } \\
\text { beyond normal commercial } \\
\text { this selectively. In reality, all } \\
\text { standard, not focusing on } \\
\text { subscribers in France were } \\
\text { included as part of the } \\
\text { profitable/non profitable. } \\
\text { calculation. }\end{array}$ & $\begin{array}{l}\text { directly from universal service } \\
\text { provision. Provider must not } \\
\text { be burdened but equally may } \\
\text { not get financial benefit from } \\
\text { it. Only costs from non- } \\
\text { profitable activities are } \\
\text { relevant. The French } \\
\text { legislation does not limit costs } \\
\text { included sufficiently. }\end{array}$ \\
\hline
\end{tabular}




\begin{tabular}{|c|c|c|}
\hline Commission's claims & France responses & Decision \\
\hline $\begin{array}{l}\text { Calculation not transparent: } \\
\text { there is no objective criteria: } \\
\text { Unclear how Pe was } \\
\text { determined. Based on } \\
\text { practices in other countries, } \\
\text { but there is no real basis- } \\
\text { first, in the countries of } \\
\text { reference the detailed billing } \\
\text { of customers is part of the } \\
\text { basic subscription and that's } \\
\text { optional for FT. This leads to } \\
\text { an artificial increase in Pe, and } \\
\text { Pe included costs from } \\
\text { maintaining the red list, which } \\
\text { P did not. }\end{array}$ & $\begin{array}{l}\text { The } 65 \text { frank price stemmed } \\
\text { from a comparison between } \\
\text { countries which lead to a } \\
\text { margin of } 55-75 \text {. So, the value } \\
\text { is sufficiently transparent. } \\
\text { Impossible before balancing to } \\
\text { identify the subscribers served } \\
\text { in accordance with normal } \\
\text { commercial standards. }\end{array}$ & $\begin{array}{l}\text { Bench marking is generally ok } \\
\text { to set prices, but must be done } \\
\text { carefully. The commission is } \\
\text { right that the range in the } \\
\text { Champsaur report is very } \\
\text { broad. So, more specifics are } \\
\text { necessary, and only costs } \\
\text { related to universal service can } \\
\text { be included. }\end{array}$ \\
\hline
\end{tabular}

Fourth complaint: using flat rate rather than calculation for certain components

\begin{tabular}{|c|c|c|}
\hline Commission's claims & France responses & Decision \\
\hline $\begin{array}{l}\text { Net cost for non-profitable } \\
\text { subscribers artificially set at } \\
\text { one percent of turnover. This } \\
\text { is higher than estimates in } \\
\text { other countries, and higher } \\
\text { than that used in France in } \\
1999-2000 \text {. }\end{array}$ & $\begin{array}{l}\text { The Champsaur report shows } \\
\text { there was no reliable way to } \\
\text { calculate costs in 1998, so } \\
\text { suggested a margin hat led to } \\
\text { one percent. Unclear if it's } \\
\text { possible to calculate } 1997 \\
\text { costs-ART does not have } \\
\text { data. Only reliable method, } \\
\text { though imprecise. Little } \\
\text { significant for cost to } \\
\text { providers-their position was } \\
\text { minor in these years. }\end{array}$ & \multirow[t]{2}{*}{$\begin{array}{l}\text { The directive requires a } \\
\text { precise calculation of net cost, } \\
\text { and states how the costs are to } \\
\text { be calculated. It therefore does } \\
\text { not permit a flat-rate } \\
\text { calculation. The 1997-1998 } \\
\text { system is therefore flawed. }\end{array}$} \\
\hline $\begin{array}{l}\text { Geographical component was } \\
\text { calculated as three percent of } \\
\text { turnover. Unclear how amount } \\
\text { arrived at, although elements } \\
\text { are mentioned. }\end{array}$ & $\begin{array}{l}\text { Three percent stemmed from } \\
\text { an international comparison- } \\
\text { a pragmatic approach. A } \\
\text { complex calculation would } \\
\text { only lead to a very marginal } \\
\text { change. } 1999 \text { methodology } \\
\text { can be used to 1997-98, but } \\
\text { it's really difficult. And } \\
\text { allowing the precedent of } \\
\text { choosing another methodology } \\
\text { will lead to uncertainty for } \\
\text { traders. }\end{array}$ & \\
\hline
\end{tabular}




\begin{tabular}{|l|l|l|}
\hline Commission's claims & France responses & Decision \\
\hline Hardship tariffs: calculations & In 1999 a new system was & \\
imprecise. Change of system & introduced, with reduction for \\
does not fix the infringement. & $\begin{array}{l}\text { minimum wage earners and } \\
\text { disabled veterans. In special } \\
\text { cases the state assumed } \\
\text { specific debts. }\end{array}$ & \\
\hline
\end{tabular}

Fifth Complaint: other components of universal service drawn to increase costs

\begin{tabular}{|c|c|c|}
\hline Commission's claims & France responses & Decision \\
\hline $\begin{array}{l}\text { Calculation of net cost of non- } \\
\text { profitable zones: does not } \\
\text { include proceeds from } \\
\text { inclusion in red list and } \\
\text { comfort services. No intent to } \\
\text { remedy the pre } 1999 \text { situation. } \\
\text { Publication of directory } \\
\text { separate from red list. }\end{array}$ & $\begin{array}{l}\text { Costs and proceeds of comfort } \\
\text { services only taken into } \\
\text { account since 1999; red list } \\
\text { cannot be separated from the } \\
\text { publication of an annual } \\
\text { directory. It's not a separate } \\
\text { cost components. }\end{array}$ & \multirow[t]{3}{*}{$\begin{array}{l}\text { French Government concedes } \\
\text { it did not comply with } \\
\text { directive, commission rejects } \\
\text { their claim about the red list- } \\
\text { it's separate from the } \\
\text { directory. }\end{array}$} \\
\hline $\begin{array}{l}\text { In } 1998 \text { the calculation is } \\
\text { based on traditional data, not } \\
\text { on best practice. }\end{array}$ & $\begin{array}{l}\text { As much as possible, an } \\
\text { account was taken of the } \\
\text { commission's } \\
\text { recommendations relating to } \\
\text { the application of Annex III. } \\
\text { Application of the } \\
\text { methodology of } 1999 \text { to } 1998 \\
\text { is really hard. }\end{array}$ & \\
\hline $\begin{array}{l}\text { No account of intangible } \\
\text { benefits to FT. }\end{array}$ & $\begin{array}{l}\text { Agreed-cannot estimate it } \\
\text { retroactively. }\end{array}$ & \\
\hline
\end{tabular}

Sixth Complaint

\begin{tabular}{|l|l|l|}
\hline Commission's claims & France responses & Decision \\
\hline $\begin{array}{l}\text { No reporting of the } \\
\text { contributions of parties to } \\
\text { universal service costs. }\end{array}$ & Agreed. & Complaint founded. \\
\hline
\end{tabular}


APPENDIX II: CASES BROUGHT BY COMPETITORS AGAINST THE ART'S UNIVERSAL SERVICE DETERMINATIONS $^{76}$

\begin{tabular}{|c|c|c|c|c|}
\hline $\begin{array}{l}\text { Case Number, } \\
\text { Date }\end{array}$ & $\begin{array}{l}\text { Party Bringing } \\
\text { Case }\end{array}$ & Legal Issue & Parties'Request & Court's Decision \\
\hline $\begin{array}{l}\text { 1. } 250813 \text {, } \\
\text { November } 8 \text {, } \\
2002\end{array}$ & $\begin{array}{l}\text { La Société } \\
\text { Tiscali Télécom }\end{array}$ & $\begin{array}{l}\text { Delay } \\
\text { payment } \\
\text { according to } \\
\text { ART's decision. }\end{array}$ & $\begin{array}{l}\text { That ART's } \\
\text { decision } \\
\text { requiring Tiscali } \\
\text { to pay in two } \\
\text { installments } 3, \\
670,000 \text { Euros } \\
\text { for its universal } \\
\text { service } \\
\text { contribution for } \\
2002 \\
\text { suspended. }\end{array}$ & $\begin{array}{l}\text { Grave doubt } \\
\text { about legality of } \\
\text { the decision and } \\
\text { grave damage } \\
\text { from no } \\
\text { suspension lead } \\
\text { to decision being } \\
\text { suspended. }\end{array}$ \\
\hline $\begin{array}{l}2.250608, \text { June } \\
182003\end{array}$ & $\begin{array}{l}\text { La Société } \\
\text { Tiscali Télécom }\end{array}$ & $\begin{array}{l}\text { Can the minister } \\
\text { temporarily set } \\
\text { universal service } \\
\text { contribution } \\
\text { without a new } \\
\text { system put in } \\
\text { place? }\end{array}$ & $\begin{array}{l}\text { Annulment of the } \\
\text { decree of the } \\
\text { minister setting } \\
\text { universal service } \\
\text { for } 2002 \text { and } \\
\text { costs. }\end{array}$ & $\begin{array}{l}\text { Yes, minister } \\
\text { could create a } \\
\text { temporary } \\
\text { system, but the } \\
\text { mode of } \\
\text { evaluation of } \\
\text { costs and the } \\
\text { rules of the } \\
\text { system should be } \\
\text { published. They } \\
\text { were not. } \\
\text { Decision } \\
\text { overturned for } \\
\text { lack } \\
\text { transparency. } \\
\text { Costs awarded to } \\
\text { Tiscali. }\end{array}$ \\
\hline
\end{tabular}

\footnotetext{
${ }^{76}$ In ascending order of date. All cases here were brought before the Conseil d'état.
} 


\begin{tabular}{|c|c|c|c|c|}
\hline $\begin{array}{l}\text { Case Number, } \\
\text { Date }\end{array}$ & $\begin{array}{l}\text { Party Bringing } \\
\text { Case }\end{array}$ & Legal Issue & Parties' Request & Court's Decision \\
\hline $\begin{array}{l}\text { 3. } 250643 \text {, April } \\
12005, \text { Conseil } \\
\text { D'État }\end{array}$ & Société Cegetel & $\begin{array}{l}\text { Objects to the } \\
\text { mode of } \\
\text { calculating the } \\
\text { contribution and } \\
\text { the mathematic } \\
\text { approach. }\end{array}$ & & $\begin{array}{l}\text { 1. Decree already } \\
\text { declared invalid } \\
\text { in Tiscali's case, } \\
\text { claim moot. } \\
2 . \text { For specific } \\
\text { sum-denied for } \\
\text { non exhaustion, } \\
\text { not addressing } \\
\text { minister. }\end{array}$ \\
\hline $\begin{array}{l}\text { 4. } 250644 \text {, April } \\
12005 \text {, Conseil } \\
\text { D'État }\end{array}$ & $\begin{array}{l}\text { Société Française } \\
\text { De } \\
\text { Radiotéléphone } \\
\text { (SFR) }\end{array}$ & $\begin{array}{l}\text { Objects to the } \\
\text { mode of } \\
\text { calculating the } \\
\text { contribution and } \\
\text { the mathematic } \\
\text { approach. }\end{array}$ & & $\begin{array}{l}\text { 1. Decree already } \\
\text { declared invalid } \\
\text { in Tiscali's case, } \\
\text { claim moot. } \\
2 \text {. For specific } \\
\text { sum-denied for } \\
\text { non exhaustion, } \\
\text { not addressing } \\
\text { minister. }\end{array}$ \\
\hline $\begin{array}{l}\text { 5. } 250645, \text { April } \\
12005, \text { Conseil } \\
\text { D'État }\end{array}$ & $\begin{array}{l}\text { Société } \\
\text { Réunionnaise Du } \\
\text { Radiotelephone }\end{array}$ & $\begin{array}{l}\text { Objects to mode } \\
\text { of calculating } \\
\text { contribution and } \\
\text { the mathematic } \\
\text { approach. }\end{array}$ & & $\begin{array}{l}\text { 1. Decree already } \\
\text { declared invalid } \\
\text { in Tiscali's case, } \\
\text { claim moot. } \\
2 . \text { For specific } \\
\text { sum-denied for } \\
\text { non exhaustion, } \\
\text { not addressing } \\
\text { minister. }\end{array}$ \\
\hline
\end{tabular}




\begin{tabular}{|c|c|c|c|c|}
\hline $\begin{array}{l}\text { Case Number, } \\
\text { Date }\end{array}$ & $\begin{array}{l}\text { Party Bringing } \\
\text { Case }\end{array}$ & Legal Issue & Parties' Request & Court's Decision \\
\hline $\begin{array}{l}\text { 6. } 250609 \text {, April } \\
12005, \text { Conseil } \\
\text { D'État }\end{array}$ & $\begin{array}{l}\text { Société } \\
\text { Telecom }\end{array}$ & $\begin{array}{l}\text { Objects to the } \\
\text { mode of } \\
\text { calculating the } \\
\text { contribution. }\end{array}$ & $\begin{array}{l}\text { Annulling ART's } \\
\text { decision } \\
\text { informing the } \\
\text { plaintiff of the } \\
\text { sums it needs to } \\
\text { pay in } 2002 \text {. }\end{array}$ & $\begin{array}{l}\text { Denied for non- } \\
\text { exhaustion-the } \\
\text { company did not } \\
\text { address a first } \\
\text { complaint to } \\
\text { minister; } \\
\text { decision not } \\
\text { suffering from } \\
\text { defects sufficient } \\
\text { to rend it null } \\
\text { and void. }\end{array}$ \\
\hline $\begin{array}{l}\text { 7. } 250610, \text { April } \\
12005, \text { Conseil } \\
\text { D'État }\end{array}$ & $\begin{array}{l}\text { Societe } \\
\text { Belgacom } \\
\text { Telecom France }\end{array}$ & $\begin{array}{l}\text { Objects to the } \\
\text { mode of } \\
\text { calculating the } \\
\text { contribution and } \\
\text { the mathematic } \\
\text { approach. }\end{array}$ & $\begin{array}{l}\text { Annulling ART's } \\
\text { decision } \\
\text { informing the } \\
\text { plaintiff of the } \\
\text { sums it needs to } \\
\text { pay in } 2002 \text {. }\end{array}$ & $\begin{array}{l}\text { Denied for non- } \\
\text { exhaustion. }\end{array}$ \\
\hline $\begin{array}{l}\text { 8. } 250611 \text {, April } \\
12005, \text { Conseil } \\
\text { D'État }\end{array}$ & Societe Kaptech & $\begin{array}{l}\text { Objects to the } \\
\text { mode of } \\
\text { calculating the } \\
\text { contribution and } \\
\text { the mathematic } \\
\text { approach. }\end{array}$ & $\begin{array}{l}\text { Annulling ART's } \\
\text { decision } \\
\text { informing the } \\
\text { plaintiff of the } \\
\text { sums it needs to } \\
\text { pay in } 2002 \text {. }\end{array}$ & $\begin{array}{l}\text { Denied for non- } \\
\text { exhaustion. }\end{array}$ \\
\hline $\begin{array}{l}\text { 9. } 250612 \text {, April } \\
12005, \text { Conseil } \\
\text { D'État }\end{array}$ & $\begin{array}{l}\text { Société Ventelo } \\
\text { France }\end{array}$ & $\begin{array}{l}\text { Objects to the } \\
\text { mode of } \\
\text { calculating the } \\
\text { contribution and } \\
\text { the mathematic } \\
\text { approach. }\end{array}$ & $\begin{array}{l}\text { Annulling ART's } \\
\text { decision } \\
\text { informing the } \\
\text { plaintiff of the } \\
\text { sums it needs to } \\
\text { pay in } 2002 \text {. }\end{array}$ & $\begin{array}{l}\text { Denied for non- } \\
\text { exhaustion. }\end{array}$ \\
\hline $\begin{array}{l}\text { 10. } 250614, \\
\text { April } 12005, \\
\text { Conseil D'État }\end{array}$ & $\begin{array}{l}\text { Société Louis } \\
\text { Dreyfus } \\
\text { Communication }\end{array}$ & $\begin{array}{l}\text { Objects to the } \\
\text { mode of } \\
\text { calculating the } \\
\text { contribution and } \\
\text { the mathematic } \\
\text { approach. }\end{array}$ & $\begin{array}{l}\text { Annulling ART's } \\
\text { decision } \\
\text { informing the } \\
\text { plaintiff of the } \\
\text { sums it needs to } \\
\text { pay in } 2002 \text {. }\end{array}$ & $\begin{array}{l}\text { Denied for non- } \\
\text { exhaustion. }\end{array}$ \\
\hline
\end{tabular}




\begin{tabular}{|c|c|c|c|c|}
\hline $\begin{array}{l}\text { Case Number, } \\
\text { Date }\end{array}$ & $\begin{array}{l}\text { Party Bringing } \\
\text { Case }\end{array}$ & Legal Issue & Parties' Request & Court's Decision \\
\hline $\begin{array}{l}\text { 11. } 250572, \\
\text { April } 12005, \\
\text { Conseil D'État }\end{array}$ & $\begin{array}{l}\text { S.A. Bouygues } \\
\text { Telecom }\end{array}$ & $\begin{array}{l}\text { Objects to the } \\
\text { mode of } \\
\text { calculating the } \\
\text { contribution and } \\
\text { the mathematic } \\
\text { approach. }\end{array}$ & $\begin{array}{l}\text { Annulling ART's } \\
\text { decision } \\
\text { informing the } \\
\text { plaintiff of the } \\
\text { sums it needs to } \\
\text { pay in } 2002 \text {. }\end{array}$ & $\begin{array}{l}\text { Denied for non- } \\
\text { exhaustion. }\end{array}$ \\
\hline $\begin{array}{l}\text { 12. } 251239, \\
\text { April } 112005, \\
\text { Conseil d'État }\end{array}$ & $\begin{array}{l}\text { Société Française } \\
\text { De } \\
\text { Radiotéléphone } \\
\text { (SFR), Société } \\
\text { Réunionnaise Du } \\
\text { Radiotéléphone, } \\
\text { S.A. Bouygues } \\
\text { Telecom, Société } \\
\text { Cegetel }\end{array}$ & $\begin{array}{l}\text { Changing the } \\
\text { regulation of } \\
\text { financing the } \\
\text { universal service } \\
\text { to bring it into } \\
\text { conformity with } \\
\text { EU law-current } \\
\text { modification } \\
\text { insufficient. }\end{array}$ & $\begin{array}{l}\text { Annulling the } \\
\text { minister's decree } \\
\text { ("arret") and } \\
\text { ART's } \\
\text { subsequent } \\
\text { specific } \\
\text { decisions about } \\
\text { the universal } \\
\text { service } \\
\text { contributions for } \\
2000 .\end{array}$ & $\begin{array}{l}\text { At the relevant } \\
\text { date, the law was } \\
\text { not corrected } \\
\text { according to ECJ } \\
\text { decision and } \\
\text { there was no } \\
\text { urgency to } \\
\text { demand money } \\
\text { that has been } \\
\text { spent eighteen } \\
\text { months before; } \\
\text { therefore, the } \\
\text { minister did not } \\
\text { have the } \\
\text { authority for the } \\
\text { decree. Decree is } \\
\text { annulled. } \\
\text { However, as to } \\
\text { ART's decision, } \\
\text { denied for non- } \\
\text { exhaustion. }\end{array}$ \\
\hline $\begin{array}{l}\text { 13. } 252125, \\
\text { April 11, 2005, } \\
\text { Conseil D'État }\end{array}$ & $\begin{array}{l}\text { S.A. Bouygues } \\
\text { Telecom }\end{array}$ & $\begin{array}{l}\text { Jurisdiction over } \\
\text { demand to } \\
\text { reimburse sums. }\end{array}$ & $\begin{array}{l}\text { That the } \\
\text { minister's } \\
\text { decision, } \\
\text { refusing to } \\
\text { reimburse it for } \\
\text { its contributions } \\
\text { in } 1997-2001 \text { be } \\
\text { overturn and that } \\
\text { the state } \\
\text { reimburse it. }\end{array}$ & $\begin{array}{l}\text { Denied for non } \\
\text { jurisdiction- } \\
\text { should be } \\
\text { brought to the } \\
\text { tribunal } \\
\text { administratif de } \\
\text { Versailles }\end{array}$ \\
\hline
\end{tabular}




\begin{tabular}{|c|c|c|c|c|}
\hline $\begin{array}{l}\text { Case Number, } \\
\text { Date }\end{array}$ & $\begin{array}{l}\text { Party Bringing } \\
\text { Case }\end{array}$ & Legal Issue & Parties' Request & Court's Decision \\
\hline $\begin{array}{l}\text { 14. } 250516, \text { May } \\
\text { 30, 2005, Conseil } \\
\text { D'État }\end{array}$ & \begin{tabular}{lr}
\multicolumn{2}{l}{ L'association } \\
Française Des \\
Operateurs $\quad$ De \\
Réseaux $\quad$ Et \\
Services $\quad$ De \\
Télécommunicati \\
\multicolumn{2}{l}{ ons (AFORS) }
\end{tabular} & $\begin{array}{lr}\text { Attacking } & \text { the } \\
\text { method } & \text { of } \\
\text { calculation for } \\
\text { not fitting into } \\
\text { the } \\
\text { framework and } \\
\text { distorting } \\
\text { competition. }\end{array}$ & $\begin{array}{l}\text { To force the } \\
\text { minister to repeal } \\
\text { the } 1997 \text { decree. }\end{array}$ & $\begin{array}{l}\text { Mooted because } \\
\text { decree was } \\
\text { already repealed } \\
\text { before decision. }\end{array}$ \\
\hline $\begin{array}{l}\text { 15. } 257683 \text {, } \\
\text { December } 5 \text {, } \\
2005\end{array}$ & $\begin{array}{l}\text { Bouygues } \\
\text { Telecom }\end{array}$ & $\begin{array}{l}\text { Attacking system } \\
\text { for not } \\
\text { considering } \\
\text { immaterial } \\
\text { advantage. }\end{array}$ & $\begin{array}{l}\text { To annul the } \\
2003 \text { decree for } \\
\text { not considering } \\
\text { these advantages. }\end{array}$ & $\begin{array}{l}\text { The method } \\
\text { takes those cost } \\
\text { into } \\
\text { consideration in } \\
\text { a different way; } \\
\text { the government } \\
\text { did nothing } \\
\text { wrong th } \\
\text { delegating to } \\
\text { ART the } \\
\text { authority to set } \\
\text { the method to } \\
\text { calculate those } \\
\text { benefits; there is } \\
\text { no problem with } \\
\text { the current } \\
\text { system. }\end{array}$ \\
\hline $\begin{array}{l}\text { 16. } 257747 \text {, } \\
\text { December } 5 \text {, } \\
2005\end{array}$ & \begin{tabular}{l}
\multicolumn{2}{l}{ L'association } \\
Française Des \\
Operateurs De \\
Réseaux \\
Services Et \\
Télécommunicati \\
ons (AFORS \\
Telecom).
\end{tabular} & $\begin{array}{l}\text { Attacking system } \\
\text { for not } \\
\text { considering } \\
\text { immaterial } \\
\text { advantages. }\end{array}$ & $\begin{array}{l}\text { To annul the } \\
2003 \text { decree for } \\
\text { not considering } \\
\text { these advantages. }\end{array}$ & $\begin{array}{l}\text { System is ok } \\
\text { (addressing } \\
\text { substance). } \\
\text { Reread. }\end{array}$ \\
\hline
\end{tabular}




\begin{tabular}{|c|c|c|c|c|}
\hline $\begin{array}{l}\text { Case Number, } \\
\text { Date }\end{array}$ & $\begin{array}{l}\text { Party Bringing } \\
\text { Case }\end{array}$ & Legal Issue & Parties' Request & Court's Decision \\
\hline $\begin{array}{l}\text { 17. } 252659 \text {, } \\
\text { December } 12 \text {, } \\
2005\end{array}$ & $\begin{array}{l}\text { S.A. Bouygues } \\
\text { Telecom }\end{array}$ & $\begin{array}{l}\text { The legality of } \\
\text { the minister } \\
\text { decreeing the } \\
\text { costs of universal } \\
\text { service for 1998- } \\
99 \text { without the } \\
\text { law being } \\
\text { changed first. }\end{array}$ & $\begin{array}{l}\text { Annulling the } \\
\text { decree and } \\
\text { ordering the } \\
\text { reimbursement } \\
\text { of the company. }\end{array}$ & $\begin{array}{l}1 . \quad \text { Decree } \\
\text { annulled-ECJ } \\
\text { overturned } \\
\text { system, new } \\
\text { system not yet in } \\
\text { place, no } \\
\text { urgency. } \\
2 . \quad \text { As for } \\
\text { reimbursement, } \\
\text { denied for lack } \\
\text { of jurisdiction, } \\
\text { should go to the } \\
\text { "Tribunal } \\
\text { Administratif de } \\
\text { Paris." }\end{array}$ \\
\hline $\begin{array}{l}\text { 18. } 262646, \\
\text { December } 12 \text {, } \\
2005\end{array}$ & $\begin{array}{l}\text { Société Française } \\
\text { De } \\
\text { Radiotéléphone } \\
\text { (SFR), Société } \\
\text { Réunionnaise Du } \\
\text { Radiotéléphone, } \\
\text { S.A. Bouygues } \\
\text { Telecom, Société } \\
\text { Cegetel }\end{array}$ & $\begin{array}{l}\text { Attacking the } \\
\text { mode } \\
\text { calculation. }\end{array}$ & $\begin{array}{l}\text { Annulment of a } \\
\text { decree. }\end{array}$ & $\begin{array}{l}\text { Denied for non- } \\
\text { exhaustion. }\end{array}$ \\
\hline $\begin{array}{l}\text { 19. } 250656,28 \\
\text { December } 2005\end{array}$ & $\begin{array}{lr}\text { L'association } \\
\text { Française } & \text { Des } \\
\text { Operateurs } & \text { De } \\
\text { Réseaux } & \text { Et } \\
\text { Services } & \text { De } \\
\text { Télécommunicati } \\
\text { ons ; } \\
\text { L'association } \\
\text { Française } \\
\text { Operateurs } & \text { Des } \\
\text { Réseaux } & \text { Et } \\
\text { Services } & \text { De } \\
\text { Télécommunicati } \\
\text { ons }\end{array}$ & $\begin{array}{l}\text { Attacking mode } \\
\text { of calculation. }\end{array}$ & $\begin{array}{l}\text { Annulling the } \\
\text { decree setting } \\
\text { sum for } 2002 \text { and } \\
\text { retroactively for } \\
1997-2000 .\end{array}$ & $\begin{array}{l}\text { Decree already } \\
\text { annulled-part } \\
\text { by minister and } \\
\text { part by decision } \\
\text { in favor of } \\
\text { Tiscali. }\end{array}$ \\
\hline
\end{tabular}

